\title{
Echocardiographic diastolic dysfunction among hypertensive patients
}

\section{Halgurd F. Ahmed *}

\section{Abstract}

Background and objective: Hypertension is a very common medical disorder, affecting nearly $40 \%$ of our population. Diastolic dysfunction is one of complications that happens and is regarded as a predictive of subsequent heart failure. The aim of this study was to determine the frequency of left ventricular diastolic dysfunction by echocardiography among hypertensive patients.

Methods: This study involved 150 hypertensive cases (82 female and 68 male) age from 25-81 years old. Transthoracic echocardiography approach, using SIEMENS SONOLINE Omnia 2005 machine with the probe of p4-2 was used by the researcher. A comparative 150 normal non-hypertensive healthy adults with hypertensive patients are examined again by echocardiography. The parameter for the diastolic dysfunction measurement is E/A ratio.

Results: It was found that $88(58.7 \%)$ of hypertensive patients have diastolic dysfunction, while $4.9 \%$ of non-hypertensive group have diastolic dysfunction with significant statistical differences between both groups ( $P<0.001$ ), who were age $>60$ years have $79 \%$, while age 25-35years old have $21 \%(P<0.001)$. Among left ventricular hypertrophy patients, $87.5 \%$, versus $12.5 \%$ have diastolic dysfunction $(P<0.001)$. Females are more liable for diastolic dysfunction, who have $70.7 \%$ than males who have $44.1 \%(P<0.001)$.

Conclusion: Diastolic dysfunction is common among hypertensive patients, particularly among females, aged, and who have echocardiographic criteria of left ventricular hypertrophy, represent risk factors for diastolic dysfunction.

Keywords: Diastolic dysfunction, Left ventricular hypertrophy, Echocardiography, Hypertension.

\section{Introduction}

An appreciation of normal diastolic function permits a better understanding of clinical features of diastolic heart failure. Cardiac function is critically dependent upon diastolic physiologic mechanisms to provide adequate left ventricular filling (cardiac input) in parallel with left ventricular ejection (cardiac output). These processes must function under a variety of physiological conditions, both at rest and during exercise. ${ }^{1}$ Events during diastole begin with the relaxation of the contracted myocardium. This is a dynamic, energydependant, process that includes two phases:

1- Isovolumic relaxation which is a period between aortic valve closure and mitral valve opening during which left ventricular pressure declines with no change in volume.

2- Autonomic relaxation which is a period between mitral valve opening and mitral valve closure during which the left ventricle fills at variable pressure. ${ }^{2}$

Diastolic dysfunction (DD) is characterized by elevated diastolic pressure in left ventricle despite normal or sub-normal diastolic volume. ${ }^{3}$ Hypertrophy of cardiac cells, increased interstitial collagen deposition or infiltration of the myocardium with amyloid proteins causes decreased distensability of the cardiac tissue. The ventricle then behaves as a balloon made

* Department of Internal Medicine, Rozh-halat Emergency Hospital, Erbil, Iraq. 
from abnormally thick rubber. Despite filling with high pressure, the volume cannot expand adequately. If the heart cannot be filled with blood easily, either the cardiac output becomes diminished or compensated increase the ventricular diastolic pressure to higher levels. ${ }^{4}$ When the left ventricular diastolic pressure is elevated, venous pressure in the lungs must also become elevated to maintain forward flow. Increased pulmonary venous pressure results in alveolar oedema making the patient to become shortness of breath. ${ }^{5}$ Echocardiography provide information regarding global diastolic function and is not affected by increasing heart rate or atrial fibrillation. ${ }^{6}$ Hypertensive patients in our locality, they were poorly compliance to the treatment, so we want to study the effect of this poor compliance on DD. Same thing detected in near developing countries. ${ }^{7,8}$

The aim of this study was to study the prevalence of left ventricular diastolic dysfunction detected by echocardiography among hypertensive patients in Erbil city.

\section{Methods}

The study was performed during $1^{\text {st }}$ of February2012 till $1^{\text {st }}$ of March 2013 in Rozh-halat Emergency Hospital, Erbil city, Kurdistan Region, Iraq.

\section{Subjects:}

One hundred fifty hypertensive patients (68 males and 82 females) compared with one hundred fifty non hypertensive patients were involved in this study, age ranges from 25-81 years old.

\section{Exclusion criteria:}

Ischemic heart disease, poor Echo window, valvular heart disease, cardiomyopathy (specially hypertrophic cardiomyopathy), congenital heart disease, diabetes mellitus, chronic Kidney disease, systolic heart failure, atrial fibrillation, severe chronic obstructive pulmonary disease, pericardial disease and those who take more than one antihypertensive drugs are excluded from the study. All the exclusion criteria's were excluded by history, physical examination, echocardiography, and other blood investigations.

Physical examination and investigation: History and clinical examination, vital signs were taken by the researcher (specialist physician). Blood pressure was measured by Mercury sphygmomanometer, systolic blood pressure $\geq 140 \mathrm{mmHg}$ and/or diastolic blood pressure $\geq 90 \mathrm{mmHg}$ on the average of two or more readings regarded as hypertension. ${ }^{9}$ All our patients were previously diagnosed and treated for hypertension, and control group were totally free of any medical disease. Pulse rate, respiratory rates were taken once. SIEMENS SONOLINE Omnia 2005 Echo machine with p2-4 probe Echocardiography was used. Definition for left ventricular hypertrophy in diastole, that depended in this study was septal thickness $>10.9 \mathrm{~mm}$ and posterior wall thickness $>11.9 \mathrm{~mm} .^{10}$ All patients and control group were examined in the left lateral position, pulse waved Doppler Mitral inflow velocities were recorded by placing sample volume at the tips of the Mitral valve. The transmitral peak early diastolic velocity $(E)$, peak late diastolic velocity $(A), E$ wave deceleration time (DT) and E/A ratio were measured. Isovolumic relaxation time (IVRT) was recorded from apical 5- chamber view by simultaneously recording of the mitral and aortic flows. Tissue Doppler Imaging was performed by activating the TDI function, to assess the diastolic function, two velocities; peak early diastolic velocity $E$ and peak late diastolic velocity $A$ at Mitral annulus was determined. Four different sites on the mitral annulus i.e. Lateral, Anterior, Septal and Inferior were selected. For lateral and septal sites apical 4-chamber view and for anterior and inferior sites apical 2-chamber views were utilised. Mean values from above four sites were used to assess global diastolic left ventricular function. Normal peak E-wave is $(\mathrm{m} / \mathrm{sec}) 0.68 \pm 0.15$, peak A-wave is $(\mathrm{m} / \mathrm{sec}) 0.69 \pm 0.17$, E/A ratio is 1.04 \pm 0.34 , IVRT $(\mathrm{m} / \mathrm{sec}) 80 \pm 20$, DT $(\mathrm{m} / \mathrm{sec})$ $184 \pm 24$. $^{11}$ 


\section{Ethical considerations:}

Approval was taken from the Research Ethics Committee of the Medical Research Centre, Hawler Medical University. Participants were fully informed about the methods and objectives of the study.

\section{Statistical Analysis:}

Statistical package for the social sciences (version 20) was used for analysis of the data. Student's t-test was used to compare between means. Unpaired t-test was used to compare between readings of case and control group. Chi square test of association (or McNemar test) was used to compare between proportions. A p-value of $\leq 0.05$ was considered as statistically significant.

\section{Results}

It was found that $88(58.7 \%)$ of hypertensive cases have DD, while $7(4.7 \%)$ of control group have DD with statistical significance $(P<0.0001)$ as shown in Table 1.

The proportion of DD increases with the progression of patients' age, with significantly association between them $(P<0.001)$ as shown in Table 2.

Female gender cases showed more DD $(70.7 \%)$ as compared with nearly same matched age group male cases (44.1\%) with a significant difference between male and female $(P<0.001)$ as shown in Table 3.

Mean body mass index in male hypertensive group was 28.2; females were 29.7, while among control group 24.1, and 24.98 respectively. Morbid obesity was found in 13 patients, and only two in control group. Regarding the types of antihypertensive drugs that given to the patients, its shown that patients on angiotensin converting enzyme inhibitors, have the lowest proportion of DD $(49 \%)$ in comparison with other treatments, while beta-blocker groups have the highest proportion $(81 \%)$ but the difference statistically was not significant, Table 4.
Table 1: Proportion of diastolic dysfunction among hypertensive cases as compare to matched age control group.

\begin{tabular}{lllll}
\hline Group & $\begin{array}{l}\text { DD[\%] } \\
\text { Present } \\
\text { No. [\%] }\end{array}$ & $\begin{array}{l}\text { Absent } \\
\text { No. [\%] }\end{array}$ & Total & p \\
\hline Hypertensive & $88[58.7]$ & $62[41.3]$ & 150 & \\
Control & $7[4.7]$ & $143[95.3]$ & 150 & 0.001 \\
Total & $95[31.7]$ & $205[68.3]$ & 300 & \\
\hline
\end{tabular}

Table 2: Age and diastolic dysfunction.

\begin{tabular}{lllll}
\hline $\begin{array}{l}\text { Age } \\
\text { (years) }\end{array}$ & $\begin{array}{l}\text { DD[\%] } \\
\text { Present } \\
\text { No. [\%] }\end{array}$ & $\begin{array}{l}\text { Absent } \\
\text { No. [\%] }\end{array}$ & Total & $\mathbf{p}$ \\
\hline $25-35$ & $7[21]$ & $26[79]$ & 33 & \\
$36-45$ & $6[43]$ & $8[57]$ & 14 & \\
$46-55$ & $9[56]$ & $7[44]$ & 16 & 0.001 \\
$56-65$ & $29[72.5]$ & $11[27.5]$ & 40 & \\
$66-75$ & $21[78]$ & $6[22]$ & 27 & \\
$>75$ & $16[80]$ & $4[20]$ & 20 & \\
\hline
\end{tabular}

Table 3: Gender and diastolic dysfunction.

\begin{tabular}{lllll}
\hline Gender & $\begin{array}{l}\text { DD[\%] } \\
\text { Present } \\
\text { No. [\%] }\end{array}$ & $\begin{array}{c}\text { Absent } \\
\text { No. [\%] }\end{array}$ & Total & $\mathbf{p}$ \\
\hline Male & $30[44.1]$ & $38[65.9]$ & 68 & \\
Female & $58[70.7]$ & $24[29.3]$ & 82 & 0.001 \\
Total & $88[58.7]$ & $62[41.3]$ & 150 & \\
\hline
\end{tabular}

Table 4: Medication used by the patients.

\begin{tabular}{lllll}
\hline Drugs & $\begin{array}{l}\text { DD[\%] } \\
\text { Present } \\
\text { No. [\%] }\end{array}$ & $\begin{array}{c}\text { Absent } \\
\text { No. [\%] }\end{array}$ & Total & $\mathbf{p}$ \\
\hline $\begin{array}{l}\text { Angiotensin } \\
\text { receptor blocker }\end{array}$ & $20[49]$ & $21[51]$ & 41 & 0.3 \\
$\begin{array}{l}\text { Angiotensin con- } \\
\text { verting enzyme } \\
\text { inhibitor }\end{array}$ & $17[47.5]$ & $19[52.5]$ & 36 & 0.3 \\
$\begin{array}{l}\text { Calcium channel } \\
\text { blocker }\end{array}$ & $14[53.5]$ & $12[46,5]$ & 26 & 0.8 \\
$\begin{array}{l}\text { Beta-blocker } \\
\begin{array}{l}\text { Diuretics } \\
\hline\end{array}\end{array}$ & $24[81]$ & $3[19]$ & 16 & 0.13 \\
\hline
\end{tabular}


Left ventricular hypertrophy which could be seen in hypertensive cases and detected by echocardiography are found to be significantly increases the proportion of DD $(87.5 \%)$ compared to $(37.2 \%)$ with normal ventricular group that has DD $(P<0.001)$ and shown in Table 5 .

Selected wall thickness in diastole, specifically interventricular septal thickness increased to $86(76 \%)$ among hypertensive with DD compared to only two (5.5\%) of normal septum with DD ( $P<0.001)$. Posterior wall thickness increased to 57 (74\%) of cases with DD compared to 31 $(42.5 \%)$ of normal posterior wall with DD $(P<0.001)$ as shown in Table 6.

Table 5: Left ventricular hypertrophy and diastolic dysfunction.

\begin{tabular}{lllll}
\hline Group & $\begin{array}{l}\text { DD[\%] } \\
\text { Present } \\
\text { No. [\%] }\end{array}$ & $\begin{array}{l}\text { Absent } \\
\text { No. [\%] }\end{array}$ & Total & $\mathbf{p}$ \\
\hline $\begin{array}{l}\text { Left } \\
\text { ventricular } \\
\text { hypertrophy }\end{array}$ & $56[87.5]$ & $8[12.5]$ & 64 & \\
$\begin{array}{l}\text { Normal } \\
\text { ventricular } \\
\text { wall }\end{array}$ & $32[37.2]$ & $54[62.8]$ & 86 & 0.001 \\
Total & $88[58.7]$ & $62[41.3]$ & 150 & \\
\hline
\end{tabular}

Table 6: Diastolic dysfunction according to septal and posterior wall thickness.

\begin{tabular}{lllll}
\hline $\begin{array}{l}\text { Wall } \\
\text { thickness }\end{array}$ & $\begin{array}{l}\text { DD[\%] } \\
\text { Present } \\
\text { No. [\%] }\end{array}$ & $\begin{array}{l}\text { Absent } \\
\text { No. [\%] }\end{array}$ & Total & p \\
\hline $\begin{array}{l}\text { Increase } \\
\text { septal } \\
\text { thickness }\end{array}$ & 86[76] & 27[24] & 113 & \\
$\begin{array}{l}\text { Normal } \\
\text { septal } \\
\text { thickness }\end{array}$ & $2[5.5]$ & $35[94.5]$ & 37 & \\
$\begin{array}{l}\text { Increase } \\
\text { posterior } \\
\text { wall }\end{array}$ & $57[74]$ & $20[26]$ & 77 & \\
$\begin{array}{l}\text { Normal } \\
\text { posterior } \\
\text { wall }\end{array}$ & $31[42.5]$ & $42[57.5]$ & 73 & 0.001 \\
\hline
\end{tabular}

\section{Discussion}

The study shows that among hypertensive patients, $58.7 \%$ of cases have DD, while only $4.9 \%$ of non-hypertensive patients have DD. Levy et al showed that DD is more common in hypertensive patients by more than three folds in comparison to normotensive group, that's nearly the same result was found in the present study. ${ }^{12}$ The occurrence of DD in hypertensive patients increases with age, in which $80 \%$ of patients with DD their age was more than 70 years old, Donald et al showed that the incidence of DD in the 80 years of age is double risk than in the 40 years of age. ${ }^{13}$ In this study female patients have more DD $(70.7 \%)$ than male patients $(44.1 \%)$ with a significant difference $(P<0.001)$, Masoudi et al showed $79 \%$ of DD among female patients versus $21 \%$ among male patients. ${ }^{14} \mathrm{~A}$ greater decline in diastolic function is seen in hypertrophied hearts, the result shows that increase in the septal thickness is a risk for development of DD, since $76 \%$ of those with increased septal thickness have DD and $74 \%$ of those with increased posterior wall thickness have DD $(P<0.001)$. Drazner et al showed $75 \%$ DD for both septal and posterior wall hypertrophy. ${ }^{15}$ Among patients with left ventricular hypertrophy, $87.5 \%$ have DD, while only $12.5 \%$ have no $\mathrm{DD}$, the reason may be due to the fact that $12.5 \%$ have no DD probably due to lack in estimation of left ventricular mass for diagnosis of left ventricular hypertrophy which is more accurate $(P<0.001)$. Koren et al proved that upon 10years of follow up of hypertensive patients with left ventricular hypertrophy, and hypertensive patients without left ventricular hypertrophy revealed that $76 \%$ have DD in left ventricular hypertrophy group, while only $12 \%$ have DD in non-left ventricular hypertrophy group. ${ }^{16}$ Drugs which were taken by the patients, for controlling hypertension, beta-blockers associated with $81 \%$ of DD, while only $19 \%$ of them have no DD, the difference was not significant statistically, same result founded by Che et al. ${ }^{17}$ 
Among hypertensive patients receiving angiotensin converting enzyme, $47.5 \%$ of them have DD, while $52.5 \%$ of them have no DD, the difference was not significant statistically. Angiotensin receptor blocker groups showed that $49 \%$ of patients have $\mathrm{DD}$, while $51 \%$ have no DD, again with non-significant differences; Warner et al noticed an improvement of DD with losartan treatment. ${ }^{18}$ Calcium channel blocker group showed that $53.5 \%$ of patients have DD, while $46.5 \%$ of them have no DD, with non-significant difference, William et al showed certain calcium channel blockers improve DD. ${ }^{19}$ This difference is possibly because of patient's noncompliance to the treatment. The study shows that $77 \%$ of patients using thiazide diuretics have DD, while $23 \%$ of them have no DD, with no significant differences $(P<0.08)$, but Mottran et al showed that hypertensive patients with DD were given spironolactone $25 \mathrm{mg} /$ day for 6 months showed clinical improvement and echocardiographic criteria by decreasing in the septal and posterior wall thickness. ${ }^{20}$

\section{Conclusion}

Diastolic dysfunction is common among hypertensive patients and regarded as a risk factor, especially if this associated with echocardiographic criteria for left ventricular hypertrophy, and more common among older age and female sex patients.

\section{Conflicts of interest}

The author reports no conflicts of interest.

\section{Acknowledgment:}

The study was sponsored by Hawler Medical University. Thanks to Assistant Prof. Dr. Sherzad Ali for his cooperation and beneficial comments on this study. Thanks to the participants in the study.

\section{References}

1. Thais C, Barry A, Patricia A, Stephen T, Iftikhar J. Sex Differences in Arterial Stiffness and Ventricular-Arterial Interactions. J Am Coll Cardiol 2013; 61(1):96-103.
2. Aaron M, Christopher G, Horng $H$. The Development of Heart Failure in Patients with Diabetes Mellitus and Pre-Clinical Diastolic Dysfunction : A Population-Based Study. J Am Coll Cardiol 2010; 55(4):300-5.

3. Paul M, John A, Lisa C, Sherry L, Lynn K, Kent R,et al. Impaired Natriuretic and Renal Endocrine Response to Acute Volume Expansion in Pre-Clinical Systolic and Diastolic Dysfunction. J Am CollCardiol 2011;58(20):2095-103.

4. Owan TE, Hodge DO, Herges RM, Jacobsen SJ, Roger VL, Redfield MM. Trends in prevalence and outcome of heart failure with preserved ejection fraction, N Engl J Med 2006; $355: 251-9$

5. Frank E,Götz G, Hans-Dirk D, Stefan F, Rolf W, Raoul S, et al. Exercise Training Improves Exercise Capacity and Diastolic Function in Patients with Heart Failure with Preserved Ejection Fraction: Results of the Ex-DHF (Exercise training in Diastolic Heart Failure) Pilot Study.J Am Coll Cardiol 2011; 58(17):1780-91.

6. Rowlens $M$, Rakesh $M$, James $B$, Kent $R$, Naser M, Jae K, et al. Diastolic Dysfunction in Patients Undergoing Cardiac Surgery: A Pathophysiological Mechanism Underlying the Initiation of New-Onset Post-Operative Atrial Fibrillation. J Am CollCardiol 2011; 58(9):953-61.

7. Abdul Rashid K, Muhammad Q. Association and pattern of diastolic dysfunction in patients of metabolic syndrome.J Ayub Med Coll Abbottabad 2008; 20(2):70-5

8. Patil M, Burji N, Echocardiographic evaluation of diastolic dysfunction in hypertensive patients. J Assoc Physicians India 2012; 60:23-6.

9. The Eighth Report of the Joint National Committee on Prevention, Detection, Evaluation and Treatment of High Blood Pressure. US Department of Health and Human Services./ guidelines/hypertension/jnc8. Accessed January 6, 2014.

10. Meijs $M$, Bots M,Vonken E, Cramer M, Melman $P$, Velthuis $B$, et al. A prediction model for left ventricular hypertrophy in hypertension. Neth Heart J 2007; 15(9): 295-8.

11. TromsS.Mitral flow derived Doppler indices of left ventricular diastolic function. Eur. heart J 2000; 21: $1376-86$

12. Levy D, Larson M,Vasan R, Kannel W. The progression from hypertension to congestive heart failure. JAMA 1996; 275:1557-62.

13. Donald $M$, Larson $M$, Leip $E$. Lifetime risk for developing congestive heart failure. Circulation.2002; 106:3068-9.

14. Masoudi F,Havranek E, Smith G. Gender, age, and heart failure with preserved left ventricular systolic function. J Am Coll Cardiol 2003; 41:21722.

15. Drazner MH, Rame JE, Marino EK, Gottdiener JS, Kitzman DW, Gardin JM, et al. Increased left ventricular mass is a risk factor for the development of a depressed left ventricular 
ejection fraction within five years: the Cardiovascular Health Study. J Am CollCardiol 2004; 43:2207-15.

16. Koren M, Devereux R, Casale P. Role of left ventricular mass and geometry to morbidity and mortality in uncomplicated essential hypertension. Ann Intern Med 1991; 114:345-8.

17. Che Q, Martin J, Mohammed A. Beta-blockers for hypertension: Are they going out of style? Cleve Clin J Med 2009; 76(9):533-42.

18. Warner J, Metzger C, Kitzman D. Losartan improve exercise tolerance in patients with diastolic dysfunction and hypertensive response to exercise. J Am Coll Cardiol 1999; 33:1567-71.

19. William W, Parmley M. Efficacy and Safety of Calcium Channel Blockers in Hypertensive Patients with Concomitant Left Ventricular Dysfunction. Clin. Cardiol 1992; 15:235-42.

20. Mottram P, Haluska B, Leano R. Effect of aldosterone antagonism on myocardial dysfunction in hypertensive patients with diastolic heart failure. Circulation 2004; 110:558-63. 